\title{
Requirement of Polysialic Acid for the Migration of the O-2A Glial Progenitor Cell from Neurohypophyseal Explants
}

\author{
Cheng Wang, ${ }^{1}$ Genevieve Rougon, ${ }^{2}$ and Jozsef Zoltan Kiss' \\ ${ }^{1}$ Institute of Histology and Embryology, University of Geneva Medical School, $\mathrm{CH}-1211$ Geneva 4, Switzerland and \\ ¿Laboratoire de Génétique et Physiologie du Développement, F-13288 Marseille Cedex 9, France
}

While the capacity of $0-2 \mathrm{~A}$ oligodendrocyte progenitors to migrate in cell culture and during in vivo myelin formation is well documented, little is known about factors that regulate the motility of these cells. Here, we report on an in vitro model that allowed us to evaluate the contribution of $\alpha$ 2-8 linked polysialic acid (PSA) to 0-2A cell motility. Using explant cultures of newborn rat neurohypophysis, we observed that individual glial fibrillary acidic protein (GFAP)-positive cells rapidly disperse from the explants, and that cells of the O-2A lineage predominate in the migratory cell pool. Presumed O-2A progenitor cells had a round or bipolar morphology and presented both A2B5 and GFAP immunoreactivity. When cultured in medium containing $10 \%$ fetal calf serum, these cells differentiated into stellate-shaped, A2B5/GFAP-positive type 2 astrocytes. In serum-free medium most of them developed into $04 /$ galactocerebroside-positive oligodendrocytes. O-2A lineage cells were found only in a specific developmental period extending from embryonic day 21 to postnatal day 3 . A monoclonal antibody, which recognizes the $\alpha$ 2-8 linked PSA, characteristic of the embryonic form of NCAM, revealed immunoreactivity on the surface of 0-2A progenitor cells, whereas mature oligodendrocytes, type 2, type 1 astrocytes as well as flat GFAP-negative cells were negative. Treatment of the explants with endoneuraminidase purified from phage $K 1$, which specifically removes PSA from the surface of the cell, resulted in a complete blockade of the dispersion of O-2A lineage population from the explant. The effects of the enzymatic treatment were both selective and reversible: $\mathrm{mi}-$ gration of GFAP-negative fibroblast-like cells that are normally PSA negative was not influenced, and upon removal of the enzyme, cells of the O-2A lineage were readily detectable in the migrating population. These results provide direct evidence that $\alpha$ 2-8 linked PSA contribute to the motility of $0-2 A$; glial progenitor cells.

[Key words: polysialic NCAM, migration, O-2A cell, type 2 astrocyte, oligodendrocyte, neurohypophysis]

\footnotetext{
Received July 29, 1993; revised Nov. 12, 1993; accepted Jan. 27, 1994.

We thank C. Saadi for technical assistance, J.-P. Gerber for photographic work, and $J$. Ciesielski-Treska for the kind gift of anti-vimentin antibody. This work was supported by the Swiss National Science Foundation Grant 31-32745.91 to J.Z.K., the Association Française contre la Myopathie and Association de Recherche contre le Cancer (to G.R.), and EEC Biotechnology concerted action (Grant 920326 to J.Z.K. and G.R.).

Correspondence should be addressed to J. Z. Kiss, Institute of Histology and Embryology, University of Geneva Medical School, 1 rue Michel Servet, $\mathrm{CH}$ 1211 Geneva 4, Switzerland.

Copyright @ 1994 Socicty for Neuroscicncc 0270-6474/94/144446-12\$05.00/0
}

The bipotential O-2A progenitor has been identified in vitro as a precursor cell that give rise to oligodendrocytes, the myelin forming cell in the CNS, and type 2 astrocytes (Abney et al., 1981). Since thcir initial characterization in neonatal rat optic nerve cultures (Raff et al., 1983), O-2A cells with analogous morphological, antigenic, and developmental features have been isolated from various regions of the CNS (Williams et al., 1983; Levi et al., 1986; Behar et al., 1988; Dutly and Schwab, 1991). In culture, the O-2A progenitor is a small, round or processbearing bipolar cell, which binds antibodies directed against cell surface gangliosides including A2B5 and GD3 (Abney et al., 1981; Raff et al., 1983; LeVine and Goldman, 1988). In addition, it expresses the intermediate filament protein vimentin, but not galactocerebroside $(\mathrm{GalC})$ or glial fibrillary acidic protein (GFAP), characteristic of oligodendrocytes and astrocytes, respectively (see Raff, 1989, for review). As the progenitor differentiates, it acquires a multiprocess shape and expresses immunoreactive sulfated glycolipids O4 (Dubois-Dalcq, 1987). Finally, this intermediate form differentiates into an oligodendrocyle that expresses GalC and later on myelin proteins (Dubois-Dalcq et al., 1986). The O-2A cell has been recognized as bipotential since under appropriate conditions it can also give rise to type 2 astrocyte (Raff et al., 1983). Type 2 astrocytes have a multipolar, stellate form and present A2B5 and GFAP immunoreactivity. They can be distinguished from type 1 astrocytes, which display a flat fibroblast-like form, are A2B5 negative, and develop from a different type of precursor cell (see Cameron and Rakic, 1991, for review). Factors that influence the differentiation and proliferation of the $\mathrm{O}-2 \mathrm{~A}$ precursor cell in vitro have been identified (Raff et al., 1983, 1988; McMorris et al., 1986; Lillien et al., 1988). In serum-free, chemically defined medium, the precursor gives rise to oligodendrocytes by default. The development of type 2 astrocytes in serum-free cultures requires the presence of soluble (ciliary neurotrophic factor provided by type 1 astrocytes) and nondiffusible (extracellular matrix components probably deposited by mesenchymal cells) inducing factors (Lillien et al., 1988). When O-2A cclls are cultured in medium containing $10 \%$ fetal calf serum, they also differentiate into type 2 astrocytes. Although type 2 astrocytes are well established cells in vitro, whether they occur in the brain is still debated (Miller et al., 1985; Lillien and Raff, 1990; Skoff, 1990).

O-2A progenitor cells are highly motile, capable of long-distance migration that appears to be critical for myelin formation (Lachapelle et al., 1984; Small et al., 1987; Balaban and Small, 1989; Jacque et al., 1992). Myelinization is a late step in the development of the nervous system that continues into the late 
postnatal period (Benstedt et al., 1957; Hartman et al., 1979; Kristensson et al., 1986; Schwab and Schnell, 1989). In the rat optic nerve, for instance, $\mathrm{O}-2 \mathrm{~A}$ cells are not present until the perinatal period, that is, before that growing axons have established contact with their target (Small et al., 1987). O-2A cells migrate from the germinal matrix of the subventricular zone (Levison and Goldman, 1993), proliferate, and gradually spread along the developing nerve during the postnatal period. Studies using retroviral-mediated gene transfer (Levison and Goldman, 1993) have demonstrated that progenitor cells from the subventricular zone can differentiate into both oligodendrocyte and astrocyte. This sequence of developmental events, that is, myelinization follows the establishment of fiber contacts, appears important since recent studies provided evidence that oligodendrocytes and central myelin exhibit molecules that are inhibitory for axonal growth (Schwab and Caroni, 1988).

The capacity for long-distance migration of early O-2A progenitor cells has also been demonstrated in vitro. For example, cells migrating out of explants of neonatal and adult optic nerves were capable of myelinating cocultures of cerebellar explants (Wolf et al., 1986). Little is known about factors that regulate the migration of oligodendrocyte progenitor. Evidence suggests that these cells selectively migrate toward platelet-derived growth factor (PDGF) but not toward laminin (Noble et al., 1988). Among likely candidates are the adhesion molecules including the neural cell adhesion molecule (NCAM).

NCAM is an abundant membrane protein that can promote cell-to-cell adhesion through a homophilic binding mechanism (Rutishauser et al., 1982). Their adhesive properties vary with the carbohydrate content of the molecule (Hoffman and Edelman, 1983; Rutishauser et al., 1988). Though NCAM has multiple carbohydrate attachment sites (Watanabe et al., 1986), modulation of adhesion specifically arises from the length of linear polymers of $\alpha$ 2-8 linked neuraminic acid (polysialic acid, PSA). The carbohydrate polymer, $\alpha$ 2-8 linked PSA on NCAM (PSA-NCAM) has been shown to decrease homophilic binding and thereby to attenuate cell adhesion (Hoffman and Edelman, 1983; Sadoul et al., 1983). The molecular mechanism whereby PSA on NCAM modulates cell adhesion remains an open question. Several studies are consistent with a direct effect on NCAMmediated adhesion; enzymatic removal of PSA increases binding between NC.AM-bearing liposomes and neuroblastoma cells (Sadoul et al., 1983) and the rate of NCAM-dependent aggregation of membrane vesicles in vitro (Hoffman and Edelman, 1983; Rutishauser et al., 1985). Specific loss of PSA from NCAM increases the relative degree of overall membrane-membrane apposition between cells (Rutishauser et al., 1988). These and other studies on a variety of cell-cell interactions have led to the alternative or supplemental hypothesis that PSA could affect not only NCAM functions, but also other ligands not directly involved in NCAM-mediated adhesion (Rutishauser et al., 1988; Acheson et al., 1991). Thus, it has been proposed that PSA on NCAM is a potent regulator of cell interactions involving membrane contact (Rutishauser et al., 1988).

The O-2A progenitor cell expresses the highly sialylated form (PSA-NCAM), whereas mature oligodendrocytes or type 2 astrocytes display the adult isoform with a lower content of sialic acid (Trotter et al., 1989). Based on this, it has been suggested that PSA facilitates the motility of the O-2A progenitor.

To assess the suggested participation of PSA in O-2A migration we took advantage of an explant culture model of the rat neurohypophysis (NH). The $\mathrm{NH}$ is a circumventricular organ characterized by a high density of capillaries that lack the bloodbrain barrier. These capillaries are the target of a prominent fiber tract, the hypothalamo-neurohypophyseal system, from which the neurohormones oxytocin and vasopressin are released into the general circulation (see Hatton, 1990, for review). The principal cellular element of the NH is a specialized astrocyte referred to as pituicyte (Suess and Pfister, 1981; Salm et al., 1982). These cells have characteristics of astrocytes (e.g., recognized by antibodies against GFAP) and feature a remarkable process motility in response to diverse physiological stimuli (Theodosis and Poulain, 1984; Hatton, 1990). This capacity appears to be the basis of a reversible reorganization of the neurohypophysial structure in adults under conditions of stimulated hormone release (Theodosis and Poulain, 1984; Hatton, 1990). It is of interest that pituicytes in the adult NH retain the capacity to express highly polysialylated isoforms of NCAM (Theodosis et al., 1991; Kiss et al., 1993). Moreover, the presence of PSA-NCAM on pituicytes seems to be dependent on interactions between neurosecretory axons and pituicytes (Kiss et al., 1993). To study these interactions, we established organocultures of $\mathrm{NH}$. In these preparations nerve fibers degenerate and the major cellular elements are pituicytes along with endothelial cells, and fibroblasts. Here we report that during a specific developmental period, the cellular outgrowth around pituitary explants is rich in cells with properties similar to those previously described for cells of the O-2A lineage. We found that migrating $\mathrm{O}-2 \mathrm{~A}$ progenitor cells express immunoreactivity for the PSA isoform of NCAM and we set out to determine the possible role of this carbohydrate on the migratory properties of these cells.

A preliminary report of these findings has been presented in abstract form (Wang et al., 1993).

\section{Materials and Methods}

Animals. Sprague-Dawley (SIVZ, Zurich, Switzerland) rat pups were raised in our breeding colonies. Embryonic and postnatal age was calculated counting embryonic (E) day 1 as the day after females were mated overnight and postnatal (PN) day 0 as the day of birth. The following time points were sampled: E21, and PN0, PN1, PN3, PN7, and adult.

Antibodies and Endoncuraminidase $N$. To identify astrocytes, a rabbit polyclonal antibody (Dakopatts, Denmark) and a mouse monoclonal antibody (Boehringer Mannheim) to glial fibrillary acidic protein (GFAP) were used at dilutions of 1:200 and 1:15, respectively.

Anti-vimentin, mouse monoclonal antibody (culture supernatant) was used at a dilution of 1:4 (Ciesielski-Treska et al., 1991).

Mouse monoclonal A2B5 hybridoma supernatant (ATCC, Rockville, MD; 1:5 dilution) specific to cell surface ganglioside epitopes (Eisenbarth et al., 1979) was used to label O-2A progenitor cells and type 2 astrocytes.

O4 monoclonal antibody, hybridoma supernatant (diluted 1:5) (Sommer and Schachner, 1981; Trotter and Schachner, 1989) was used to identify undifferentiated and differentiated oligodendrocytes.

Anti-galactocerebroside $(\mathrm{GalC})$ monoclonal antibody (culture supernatant) was used to identify differentiated oligodendrocytes. This antibody reacts strongly with galactocerebroside, the major galactosphingolipid of myelin (Ranscht et al., 1982). It was used at a dilution of 1:2.

Anti-Men B (Meningococcus group B) antibody is a mouse IgM that recognizes specifically $\alpha$ 2-8 linked PSA with chain length superior to 12 residues (Rougon et al., 1986; Häyrinen, personal communication). Ascites fluid was used at a dilution of 1:400.

The rabbit antiserum directed against NCAM protein core was a sitedirected antibody recognizing the seven $\mathrm{NH}_{2}$-terminal residues of NCAM whose sequence is shared by every isoform (Rougon and Marshak, 1986). It was used at a dilution of 1:1000.

The mouse monoclonal antibody against bromodeoxyuridine (BrdU) (Boehringer Mannheim) was used at a dilution of 1:50.

Purification of soluble Endo- $N$. Bacteriophage PK1 A and its propa- 

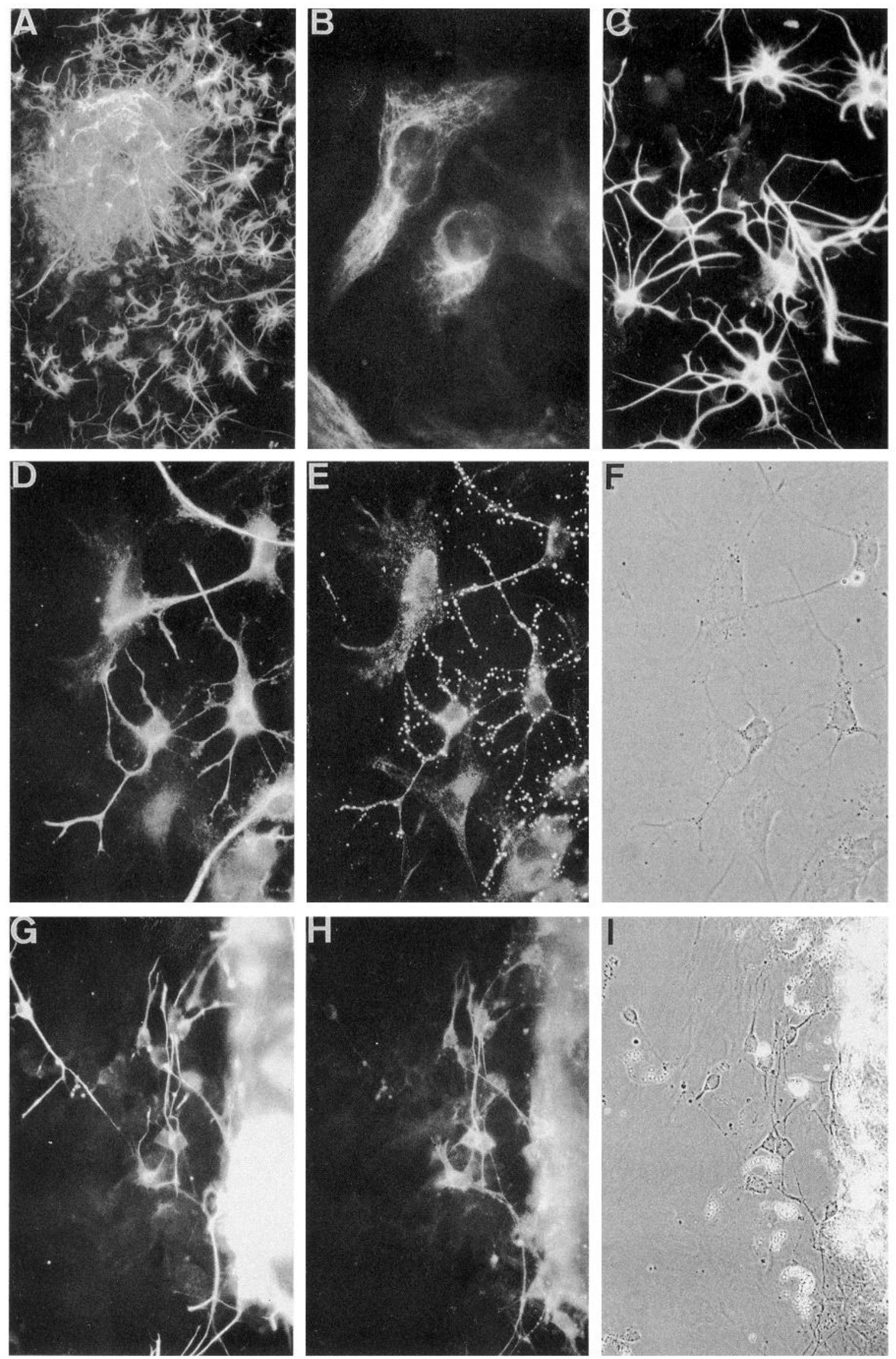
gating strain Escherichia coli U9/41 were kindly supplied by Dr. G. Alcaraz (CIML, Marseille). The purification of the bacteriophage was done as described by Finne and Mäkela (1985). Briefly, the phage was propagated in $E$. coli U9/41 grown in L broth, yeast extract (Difco), and $5 \mathrm{gm}$ of $\mathrm{NaCl} /$ liter at $\mathrm{pH}$ 7.0. The phage was inoculated in the logarithmically growing bacterial culture at $37^{\circ} \mathrm{C}$ on a rotary shaker, at a concentration of 1 plaque forming unit (pfu)/bacterium. When the initially turbid culture had cleared, chloroform was added and shaking continued for $15 \mathrm{~min}$. The culture was left $12 \mathrm{hr}$ at $4^{\circ} \mathrm{C}$, and then centrifuged $(6000 \times \mathrm{g}, 15 \mathrm{~min})$. The pellet was resuspended in $0.1 \mathrm{M}$ Tris- $\mathrm{HCl}, \mathrm{pH} 7.5$, containing $0.1 \% \mathrm{NH}_{4} \mathrm{OH}$ and $0.5 \% \mathrm{NaCl}$.

In some instances, further purification of the bacteriophage was achieved by centrifugation on a two steps gradient of $\mathrm{CsCl}$ (cesium chloride) with densities of 1.3 and $1.6 \mathrm{gm} / \mathrm{ml}$ prepared in Tris buffer The phage preparation was layered over the two layers and centrifuged at $90,000 \times g$ for $1.5 \mathrm{hr}$. and collected from the interface between the middle and the lower thirds of the gradient and dialyzed against PBS at $4^{\circ} \mathrm{C}$.

Purification of soluble Endo- $\mathrm{N}$ was conducted essentially as described by Hallenbeck et al. (1987). The phage lysate was brought to $50 \%$ saturation with $\left(\mathrm{NH}_{4}\right)_{2} \mathrm{SO}_{4}$ and stirred for $12 \mathrm{hr}$ at $4^{\circ} \mathrm{C}$.

The pellet was collected by centrifugation $(6000 \times \mathrm{g}, 30 \mathrm{~min})$, resuspended in $50 \mathrm{~mm}$ Tris $\mathrm{pH} 7.4$ containing $0.5 \mathrm{~mm}$ EDTA and 0.2 mM phenylmethylsulfonyl chloride, and sedimented at $24,000 \times g$ for $25 \mathrm{~min}$. The pellet was reextracted to recover Endo- $\mathrm{N}$ activity retained. The supernatants were pooled and centrifuged at $130,000 \times g$ for 90 min, and then heated at $55^{\circ} \mathrm{C}$ for $25 \mathrm{~min}$ and immediately centrifuged at $24,000 \times \mathrm{g}$ for $20 \mathrm{~min}$ at $4^{\circ} \mathrm{C}$. The resulting supernatant was brought to $25 \%$ saturation with $\left(\mathrm{NH}_{4}\right)_{2} \mathrm{SO}_{4}$, stirred, and centrifuged at 24,000 $\times g$ for $15 \mathrm{~min}$, and the supernatant was then brought to $40 \%$ saturation and centrifuged as above. The pellet was dissolved in a minimal volume of $20 \mathrm{~mm}$ Tris $\mathrm{pH} 7.5$ containing $0.5 \mathrm{~mm}$ EDTA and dialyzed against the same buffer. This fraction contained concentrated soluble Endo-N that can be stored at $-20^{\circ} \mathrm{C}$.

Purification to homogeneity was obtained by hydrophobic chromatography on octyl-Sepharose, followed by hydroxyapatite DEAE double column chromatography as described by Hallenbeck et al., 1987. Total enzyme activity was found to increase with each purification step following ammonium sulfate precipitation of proteins. The activity was estimated using AtT2O cells expressing PSA-NCAM as a substrate (Rougon et al. 1986). Our arbitrary unit was defined as the quantity of enzyme able to remove all PSA immunoreactivity (estimated by immunofluorescence staining with anti-Men $\mathrm{B}$ antibody) from 10,000 cells when incubated for $4 \mathrm{hr}$ at $37^{\circ} \mathrm{C}$ in $500 \mu \mathrm{l}$ of culture medium.

The purified preparation used for this study was titrated to be 3100 $\mathrm{U} / \mathrm{mg}$, with a concentration of protein of $1 \mathrm{mg} / \mathrm{ml}$ in the stock solution. The purest enzyme preparations were consistently shown to produce a single $90 \mathrm{kDa}$ reduced protein band using SDS-PAGE analysis. Purified enzyme was stored in $50 \%$ glycerol-PBS at $-20^{\circ} \mathrm{C}$ without detectable loss of activity over 6 months.

Endo- $\mathrm{N}$ is optimally active at neutral $\mathrm{pH}$ and has a strict specificity for PSA polymers with a minimum length of five $\alpha$ 2-8 linked sialyl residues. The enzyme releases oligomers of seven to nine residues (Vimr et al., 1984). Removal of PSA from NCAM was confirmed using both immunoblot and immunocytochemistry (not shown). Endo-N treatment removes PSA from NCAM without altering NCAM. In our experiments Endo-N was used at a concentration of $0.5 \mathrm{U} / \mathrm{ml}$.

Neurohypophysial cultures. Explant cultures of neural lobe were prepared from embryonic (E21), newborn (PN0), early postnatal (PN1, PN3 and PN7), and adult rats as described previously (Dellmann et al., 1991). Briefly, the hypophyses were removed with the usual aseptic procedures and then placed in a small volume of Dulbecco's Modified Eagle's Medium (DMEM; GIBCO) containing $100 \mathrm{U} / \mathrm{ml}$ penicillin and $0.15 \mathrm{mg} / \mathrm{ml}$ streptomycin or in Gey's Balanced Salt Solutions. The hypophyses were stripped of the meninges and the $\mathrm{NH}$ were removed, carefully separated from the intermediate lobe, and sectioned into small pieces. Tissue pieces were rinsed with fresh DMFM (GIBCO), and placed in the center of polylysine-coated coverslips in tissue culture dishes. The explant was covered with $1.5 \mathrm{ml}$ of culture medium and incubated at $37^{\circ} \mathrm{C}$ in an atmosphere of $5 \% \mathrm{CO}_{2}$ and $95 \%$ air for the time indicated. Cultures were maintained either in serum-containing ( $10 \% \mathrm{FCS})$ or serum-free medium. The serum-free medium was prepared by adding a supplement mixture ( $5 \mu \mathrm{g} / \mathrm{ml}$ insulin, $20 \mu \mathrm{g} / \mathrm{ml}$ lransferrin, $20 \mathrm{~nm}$ progesterone, $100 \mu \mathrm{M}$ putrescine, $30 \mathrm{~nm}$ sodium selenite) to the medium (DMEM, GIBCO) (Bottenstein, 1984). For the preparation of conditioned medium, the cerebral cortices of neonatal (PNO) rat pups were dissociated by pipetting, and then cells were collected by centrifugation and resuspended in DMEM (GIBCO) containing 10\% fetal calf serum, plated in culture dishes ( $100 \mathrm{~mm}$ diameter) and incubated at $37^{\circ} \mathrm{C}$ under $5 \% \mathrm{CO}_{2}$ for $3 \mathrm{~d}$. The culture medium was changed to serum-free medium and incubated for 2 additional days, and the medium was collected.

Effects of Endoneuraminidase $N$ treatment. Four groups of cultures were examined. Group 1 included cultures maintained in serum-containing medium for 76-96 hr. Group 2 included cultures maintained in normal, serum-containing medium in the presence of Endo- $\mathrm{N}(0.5 \mathrm{U} /$ $\mathrm{ml})$ for $40 \mathrm{hr}$. Group 3 included cultures that were maintained in serumcontaining medium, in the presence of Endo- $\mathrm{N}$ for $40 \mathrm{hr}$, and then rinsed with fresh culture medium, and reincubated with serum-containing medium for another $36 \mathrm{hr}$. Group 4 included cultures that were maintained in serum-containing medium for $28 \mathrm{hr}$, and then treated with Endo- $\mathrm{N}$ for $12 \mathrm{hr}$, rinsed with fresh cultured medium, and reincubated with serum-containing medium for another $28 \mathrm{hr}$. Cell counts presented in the text were obtained by sampling of 9-12 coverslips for each group in at least three independent experiments.

Immunocytochemistry. The indirect immunofluorescence technique was used to visualize immunoreactivities. For intracellular staining (GFAP), cultures were first washed in PBS and fixed in cold $\left(4^{\circ} \mathrm{C}\right) 4 \%$ paraformaldehyde in $0.1 \mathrm{~m}$ phosphate buffer, $\mathrm{PH} 7.2$, for $1 \mathrm{hr}$ at room temperature. Cells were permeabilized with a solution of PBS $/ 0.5 \%$ BSA $/ 0.3 \%$ Triton, and incubated with the primary antibody at $4{ }^{\circ} \mathrm{C}$ overnight. Bound antibodies were revealed with fluorescein-conjugated sheep anti-mouse Ig (diluted 1:80; Boehringer) or rhodamine-conjugated sheep anti-rabbit IgG (diluted 1:40; Boehringer) secondary antibodies (diluted in PBS $/ 0.5 \%$ BSA solution).

For double labeling, surface antigens (PSA-NCAM, A2B5, O4, GalC) were revealed first on cells fixed as above; then cells were permeabilized and incubated with the second primary antibody (GFAP), rinsed, incubated with rhodamine-conjugated sheep anti-rabbit Ig and fluorescein-conjugated sheep anti-mouse IgG. Using this procedure we found consistently a light intracellular staining with surface markers including A2B5. Therefore, we repeated experiments with surface labeling on live cells prior to fixation and permeabilization. The staining pattern after the two different protocols were similar, and results of both methods were included in the data presented. Cultures were examined with a Zeiss Axiophot fluorescence microscope.

BrdU incorporation. BrdU (Sigma), which is incorporated into replicating DNA, was added to cultures in some experiments to a final concentration of $10 \mu \mathrm{M}$ during the first 2 or $4 \mathrm{~d}$ of culture. Explants were fixed in $70 \%$ ethanol at $41^{\circ} \mathrm{C}$ for $2 \mathrm{hr}$, treated with $1 \mathrm{~N} \mathrm{HCl}$ for 15 min to denature the DNA, and double labeled with anti-BrdU monoclonal antibody and anti-GFAP polyclonal antibody. Labeled cells were visualized by immunofluorescence as described above.

\section{Results}

Identification of glia cells in the outgrowth of neurohypophysial explants

Cellular outgrowth (Fig. $1 A$ ) from NH explants was first observed after $24 \mathrm{hr}$ in culture; cells continued to move out until forming a continuous monolayer by $6-10 \mathrm{~d}$. To determine cell phenotypes, we used initially cultures kept in serum-comple-

\footnotetext{
Figure 1. Morphologies of astrocytes in the cellular outgrowths of $\mathrm{NH}$ explants from newborn rats. Cultures were maintained in serum-complemented medium for 2-3 d. Cells were double stained with GFAP and A2B5 antibodies and then incubated with the appropriate secondary antibodies conjugated to fluorescein or rhodamine. $A$, Low-power photomicrograph of an explant with a substantial number of GFAP-positive cells in the outgrowth. $B$, GFAP-positive, flat, presumed type 1 astrocytes. $C$, GFAP-positive, stellate-shaped, presumed type 2 astrocytes. $D-F$, Stellate-shaped astrocytes are intensively stained for both GFAP $(D)$ and A2B5 $(E)$. $G-I$, Presumed progenitor cells with mainly bipolar morphology are double stained for GFAP $(G)$ and A2B5 $(H)$. Magnification: $A, 94 \times ; B, 370 \times ; C-I, 234 \times$.
} 

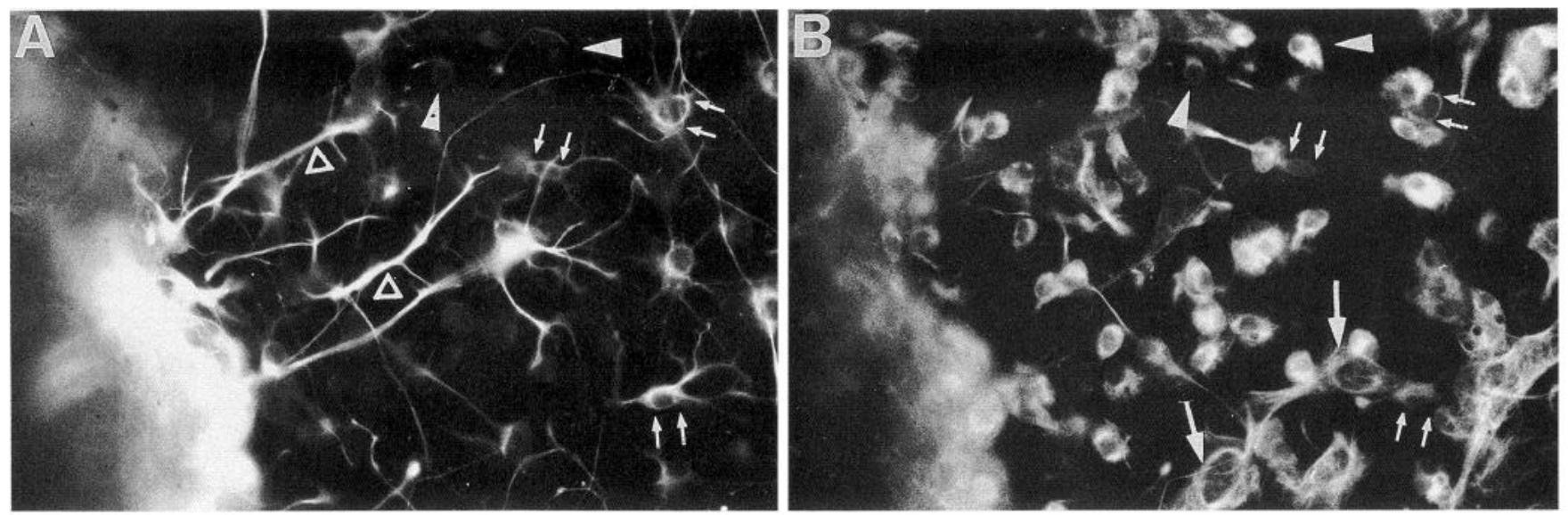

Figure 2. GFAP $(A)$ and vimentin $(B)$ immunoreactivity in cells migrated from an explant of PN0. A number of cells are double labeled with GFAP and vimentin (double arrows, arrowheads). GFAP staining is prominent in cells with branched processes (presumed type 2 astrocytes) but display a low level of vimentin immunoreactivity (double arrows). Vimentin staining is lacking in distal processes of these cells (open arrowheads). In contrast, most cells with round or bipolar morphology show intense staining for vimentin but exhibit a very low level of GFAP staining (arrowheads). Large epithelioid cells are GFAP negative and vimentin positive (arrows). Magnification, 260×.

mented milieu for $3 \mathrm{~d}$ and then fixed and processed for immunocytochemistry. Migrating cells were characterized both by morphology and double immunostaining using antibodies against the well-established astrocyte markers GFAP (Eng et al., 1971; Bignami and Dahl, 1974) and A2B5 (Abney et al., 1981). The outgrowth comprised both GFAP-negative and-positive cells. Most GFAP-negative cells were of polygonal or epithelioid shape, and stained positively for fibronectin (not shown). Two types of GFAP-positive cells could be distinguished: flat, epithelioid cells presumed to be type 1 astrocytes (Fig. $1 B$ ) and multipolar stellate cells (Fig. 1C). During the first $3 \mathrm{~d}$ in culture, virtually all stellate cells stained positively for both GFAP and A2B5 (Fig. $1 D-F$ ), suggesting that they correspond to the previously described type 2 astrocytes (Abney et al., 1981). At later times, A2B5 staining of GFAP-positive, stellate cells progressively decreased and completely disappeared after $6 \mathrm{~d}$ in vitro (data not shown). No colocalization of GFAP and A2B5 was detected in epithelioid-shaped type 1 astrocytes.

A third type of cells, immunostained for A2B5 as well as for GFAP, was also identified (Fig. $1 G-I$ ). These cells were distinguished by the light and diffuse GFAP staining in their cytoplasm (as opposed to the fibrillary appearance of GFAP staining in type 1 and 2 astrocytes) and their morphology: most of these cells were small, round or had a bipolar or unipolar morphology although occasionally multipolar cells were also found. This third type of cell was predominant during the first and second days of the culture and was most abundant in the vicinity of the explant. Since A2B5 is an established marker for O-2A oligodendrocyte progenitors and since the morphology of these cells is characteristic for nondifferentiated cells, we propose that they are O-2A progenitors. To characterize further the presumed $\mathrm{O}-2 \mathrm{~A}$ progenitors, we double stained cultures for vimentin (known to be expressed by O-2A cells) and GFAP (Fig. 2A,B). We found that most cells with round or bipolar morphology were double stained for vimentin and GFAP. The intensity of the two stainings was inversely related: cells.with simple round or bipolar morphology contained high vimentin and much less GFAP immunoreactivity, while multipolar or stellate cells were heavily labeled for GFAP but displayed a light immunostaining for vimentin. Based on the fact that progenitor type cells were weakly GFAP positive, and accompanied by a large number of type 2 astrocytes, we postulate that under our culture conditions (in serum-complemented medium) presumed precursor cells were already committed to differentiate into type 2 astrocytes.

\section{Cells of the $O-2 A$ lineage are present in the cultured explant}

To test the hypothesis that $\mathrm{O}-2 \mathrm{~A}$ progenitors are present in the cellular outgrowths of the $\mathrm{NH}$, we set up culture conditions in which progenitors should develop to oligodendrocytes (see introductory remarks). Cultures were maintained for $1 \mathrm{~d}$ in serumcomplemented and then $2 \mathrm{~d}$ in serum-free chemically defined medium, or alternatively during the whole $(3 \mathrm{~d})$ culture period in serum-free conditioned medium (see Materials and Methods). Under these conditions, bipolar cells appeared first in the outgrowth zone; then these cells rapidly differentiate into highly branched oligodendrocyte-like cells (Fig. 3A,B). Two different markers were used to identify the oligodendrocyte lineage: O4 for immature oligodendrocytes and GalC for mature oligodendrocytes. No O4- or GalC-positive cells were detected in cultures with serum-complemented medium. In contrast, cultures maintained in serum-free medium contained a large number of O4and GalC-positive cells (Fig. 3). O4-positive cells had a bipolar or multipolar morphology (Fig. $3 C, D$ ) while GalC-immunoreactive cells often had characteristic highly branched processes (Fig. 3E,F). In addition, O4-but not GalC-positive cells displayed light and diffuse GFAP staining. Type 2 astrocytes were only occasionally seen in these cultures. Thus, presumed O-2A precursors from the NH seem to be bipotential, as are the O-2A cells described in the rat optic nerve (Raff et al., 1983).

\section{Hypophysial $O-2 A$ cells are not present at all developmental stages}

To investigate whether the presence of O-2A progenitor cells depends on the developmental stage of the $\mathrm{NH}$, explant cultures of different perinatal and early postnatal age were maintained in serum-complemented medium and then double stained for GFAP and A2B5. Since virtually all type 2 astrocytes and precursor cells were immunostained for A2B5 and GFAP during the first $3 \mathrm{~d}$ in culture, we performed a quantitative analysis on explants that were maintained for $3 \mathrm{~d}$ in vitro. Data in Table 1 

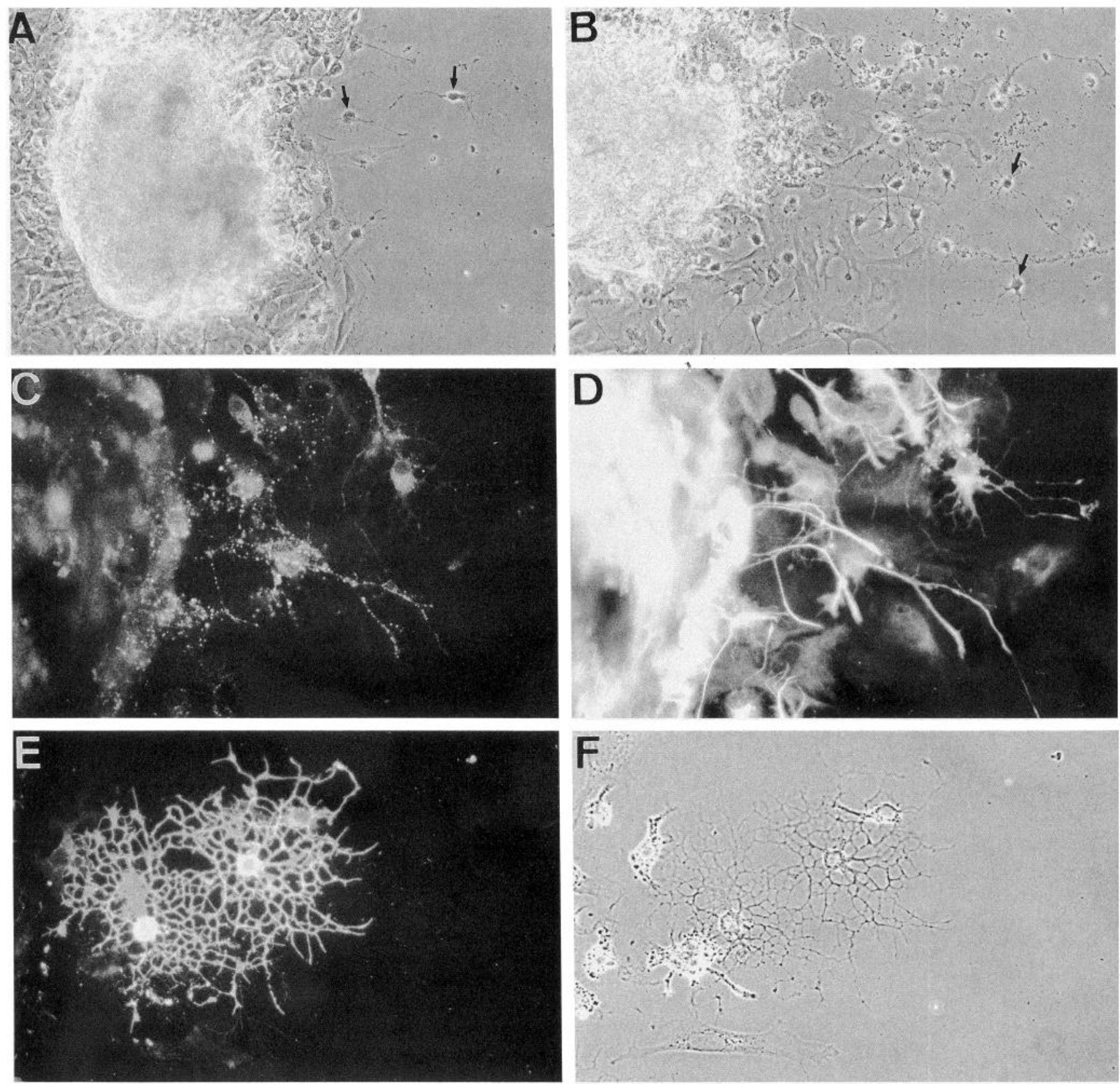

Figure 3. Morphologies of oligodendrocytes in the cellular outgrowths of NH cultured in serum-free medium for 2-3 d. $A$ and $B$, Phase-contrast photomicrographs of a live NH explant from PN0 after $2 \mathrm{~d}(A)$ and $3 \mathrm{~d}(B)$ in serum-free medium. Note the presence of presumed progenitor cells with bipolar morphology in the early phase $(A)$ of the culture, and the number of process-bearing cells $1 \mathrm{~d}$ later $(B)$. $130 \times . C$ and $D$, Immature oligodendrocytes from explants cultured for $2 \mathrm{~d}$ are intensively stained for both O4 $(C)$ and GFAP $(D)$ ). $E$ and $F$, Mature oligodendrocytes from explants cultured for $3 \mathrm{~d}$ are immunostained for GalC $(E)$. Magnification: $A$ and $B, 130 \times ; C-F, 260 \times$.

shows the relative abundance (\%) of the type 1 (flat, A2B5-/ $\mathrm{GFAP}+$ ), the type 2 astrocytes (stellate, $\mathrm{A} 2 \mathrm{~B} 5+/ \mathrm{GFAP}+$ ) and the $\mathrm{O}-2 \mathrm{~A}$ precursor (round or bipolar, GFAP $+(-) / \mathrm{A} 2 \mathrm{~B} 5+$ ) cells in the cellular outgrowth of $\mathrm{NH}$ explants taken from animals at different stages of the development. At perinatal age cells of the $\mathrm{O}-2 \mathrm{~A}$ cell lineage (precursor type and type 2 astrocyte) appeared to be predominant. In contrast, after postnatal day 3 , virtually all GFAP-positive cells were type 1, flat GFAP-positive astrocytes and no type 2 astrocytes were detected in the cellular outgrowths, though a substantial number of precursor type cell were still present. Taken together these results indicate that $\mathrm{NH}$ explants of a specific developmental period, which includes the perinatal age until postnatal day 3 , generates cellular outgrowths that are highly enriched in cells of the O-2A lineage. Since O-2A progenitor cells but neither type 2 astrocytes nor oligodendrocytes are described as highly motile cells, we postulated that progenitor cells move out from the explants and rapidly differentiate into type 2 astrocytes or oligodendrocytes depending on the presence or absence of serum in the culture medium.

\section{The majority of cells from the $O-2 \mathrm{~A}$ lineage underwent their} last division in vivo

To determine whether cells of the O-2A lineage are newly formed in culture, or residents of the $\mathrm{NH}$ in vivo, $\mathrm{NH}$ explants of $\mathrm{PN} 0$ 

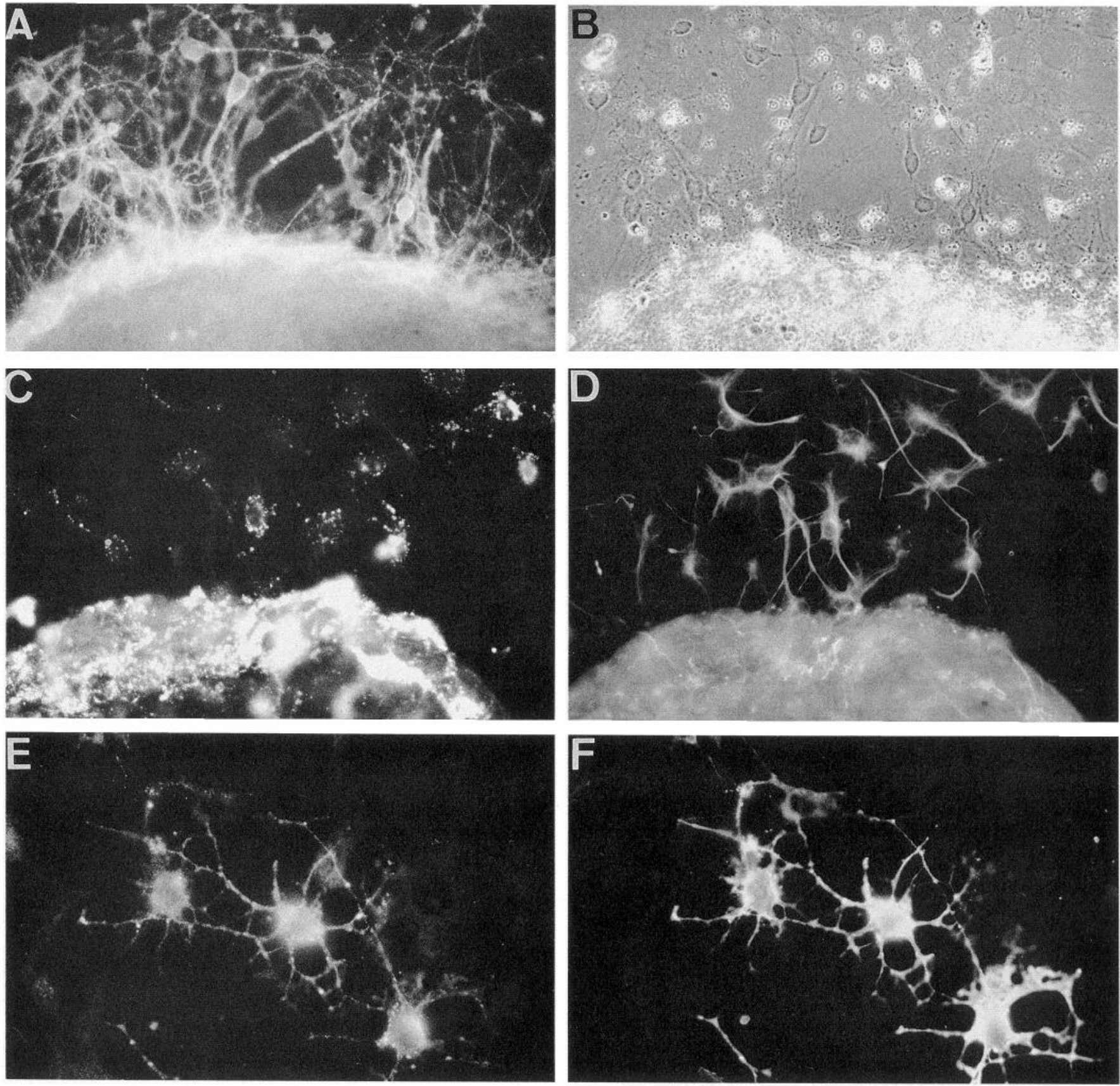

Figure 4. PSA-NCAM immunoreactivity in cells of the O-2A lineage. $A$ and $B$, PSA-positive, mostly bipolar cells from an explant of PNO that was cultured in serum-complemented medium for $24 \mathrm{hr}$. $C$ and $D$, Immature type 2 astrocytes after 36 hr in culture are immunostained for PSA $(C)$ and GFAP $(D) . E$ and $F$, Stellate-shaped, presumed type 2 astrocytes after $76 \mathrm{hr}$ in culture are immunostained for PSA $(E)$ and the NCAM protein core $(F)$. Magnification, $260 \times$.

were exposed to BrdU during the first $2 \mathrm{~d}$ of culture, and then fixed and processed for immunocytochemistry. Cells that contained incorporated BrdU were identified by the presence of immunofluorescence over their nuclei. A substantial number of BrdU-labeled nuclei were found within the explant, but only a few scattered cells were labeled in the cellular outgrowth (data not shown). GFAP-positive cells (usually 10-20) present in the vicinity of the explant, were always negative for BrdU. When explants were cultured for $4 \mathrm{~d}$ in the presence of BrdU, extensive labeling was observed mainly in peripheral zones of the cellular outgrowth. From an average of $61 \pm 10$ (mean $\pm \mathrm{SEM}, n=3$ experiments) BrdU-labeled cells per explant, $3 \%$ were found to be also GFAP positive. This represented less than $7 \%$ of the total GFAP-stained population. The average number of glial cells migrating out of the explant was similar whether the culture medium contained or lacked BrdU, indicating that the presence of BrdU did not influence the differentiation or survival of cells. These results indicate that the majority of cells of the $\mathrm{O}-2 \mathrm{~A}$ lineage are not newly formed in culture but resident of the $\mathrm{NH}$ in vivo.

\section{PSA-NCAM expression in migrating glial cells}

To correlate the expression of different forms of NCAM with glia cell types in the cellular outgrowth, cultures of perinatal $\mathrm{NH}$ 

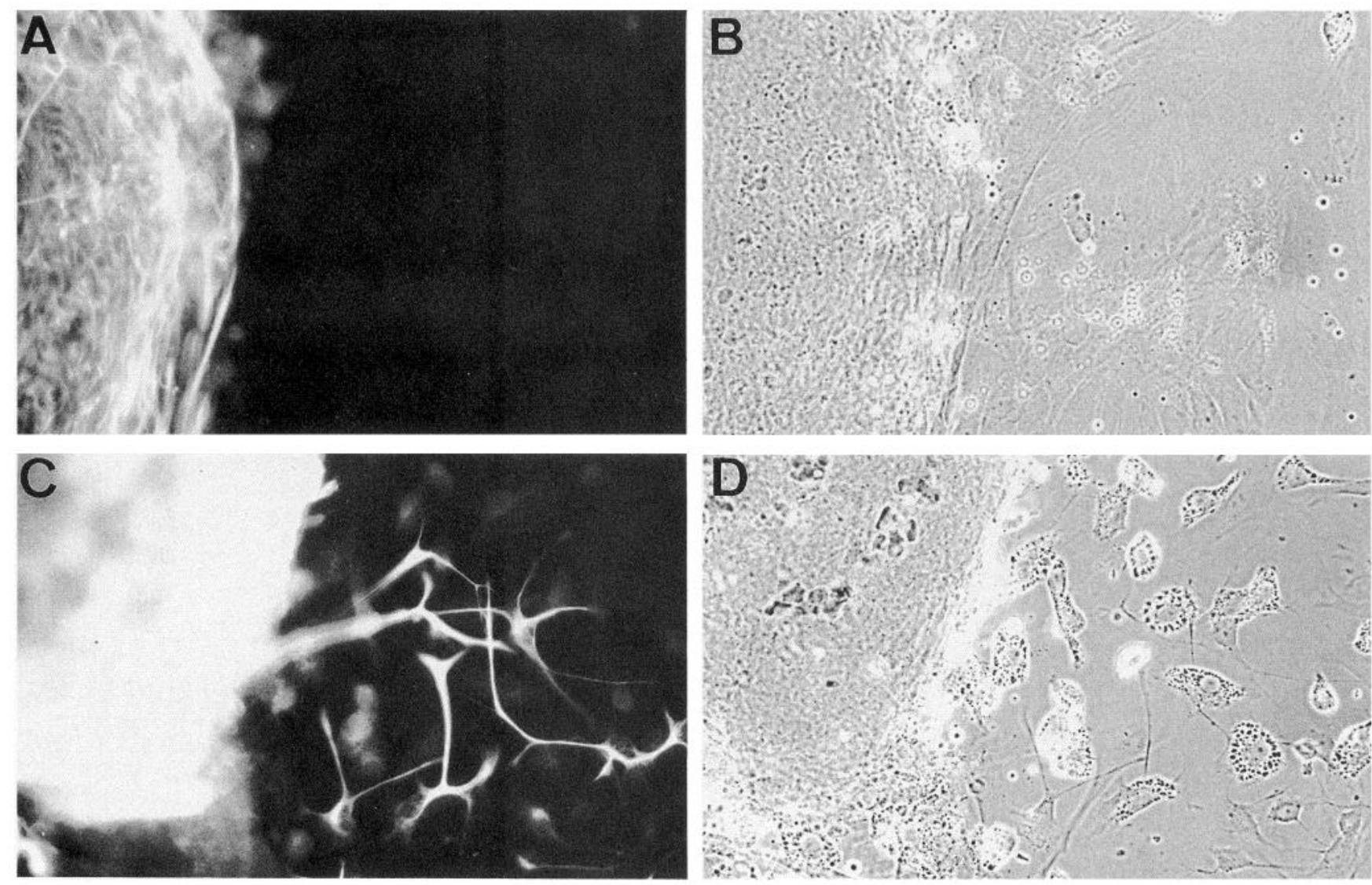

Figure 5. Effect of $40 \mathrm{hr}$ Endo-N treatment on the cellular outgrowths of explants from PN0 NH. The presence of the enzyme in the culture medium has blocked completely the migration of GFAP-positive type 2 astrocytes and precursors $(A)$, whereas the outgrowth of non-GFAP-positive cells was not affected $(B)$. Note the presence of intense GFAP staining within the explant $(A)$. The effect of Endo-N on the migration of the O-2A lineage population is reversible; GFAP-positive cells were readily detectable in the migratory population $36 \mathrm{~h}$ after cessation of the enzymatic treatment $(C, D)$. Magnification, $260 \times$.

were maintained in serum-complemented medium from 3 to 6 $\mathrm{d}$ and then fixed and double immunostained either with antibodies against PSA and GFAP or against total NCAM and GFAP. A monoclonal antibody, which recognizes the PSA structure characteristic of polysialylated isoforms of NCAM, revealed immunoreactivity mainly on the surface of small bipolar cells in the proximity of the explant (Fig. $4 A, B$ ). In addition, strong PSA immunostaining was detected at the periphery of the explanted tissue (Fig. $4 A, C$ ). After $2 \mathrm{~d}$ in serum-complemented medium, these cells acquired a multipolar morphology and displayed immunostaining for PSA as well as GFAP (Fig. $4 C, D$ ). PSA immunoreactivity on the surface of type 2 astrocytes gradually decreased and was hardly detectable by the fourth day. No PSA immunoreactivity was observed on the surface of type 1 astrocytes or on GFAP-negative epithelioid cells. Colocalization of PSA and total NCAM showed that PSA-positive cells were always immunoreactive for total NCAM (Fig. $4 E, F$ ). These results indicate, in agreement with previous data (Trotter et al., 1989), that O-2A precursors express the highly sialylated form of NCAM, and that PSA is lost as the precursor cell maturates.

\section{The enzymatic removal of PSA blocks the migration of $O-2 \mathrm{~A}$} lineage cells from $\mathrm{NH}$ explants

Previous reports indicated that the enzyme endoneuraminidase (Endo-N) is very effective in removing $\alpha$ 2-8 linked PSA from
NCAM (Rutishauser et al., 1985). To test the possible role of PSA in migration of O-2A progenitors, explants of the $\mathrm{NH}$ were cultured in serum-complemented medium in the presence of Endo- $\mathrm{N}$ for $40 \mathrm{hr}$, and then fixed and double immunostained either for GFAP/A2B5, or GFAP/PSA. For these experiments we used only NH of PNO because virtually all GFAP-positive cells in the outgrowths belong to the O-2A lineage (see Table 1). In control cultures (untreated with the enzyme) an average of $42 \pm 6$ (mean \pm SEM, $n=3$ experiments) GFAP/A2B5-

\begin{tabular}{|c|c|c|c|}
\hline $\begin{array}{l}\text { Age of } \\
\text { explant }\end{array}$ & Type 1 & Type 2 & Precursor \\
\hline E21 & $1 \pm 0.6(1 \%)$ & $35 \pm 5.0(49 \%)$ & $36 \pm 7(50 \%)$ \\
\hline PNO & $2 \pm 0.9(3 \%)$ & $35 \pm 4.0(47 \%)$ & $37 \pm 6(50 \%)$ \\
\hline PN1 & $6 \pm 1.0(6 \%)$ & $45 \pm 4.0(49 \%)$ & $41 \pm 3(45 \%)$ \\
\hline PN3 & $17 \pm 2.0(46 \%)$ & $1 \pm 0.4(3 \%)$ & $19 \pm 7(51 \%)$ \\
\hline PN7 & $16 \pm 5.0(62 \%)$ & $1 \pm 0.2(3 \%)$ & $9 \pm 3(35 \%)$ \\
\hline Adult & $13 \pm 2.0(93 \%)$ & $1 \pm 0.4(7 \%)$ & 0 \\
\hline
\end{tabular}

Neurohypophysial explants cultured for 3 d in serum-complemented medium were double stained for A2B5 and GFAP. Cell types were distinguished as follows: type 1, flat, epithelial shape, GFAP+/A2B5 -, type 2, stellate shape, GFAP+/A2B5+; progenitor, round or bipolar shape, A2B $5+/ \mathrm{GFAP}+(-)$. Numbers (mean \pm SEM) were obtained by counting cells on at least seven different coverslips, from $n=3$ separate experiments for each time point. 


\section{CONTROL}
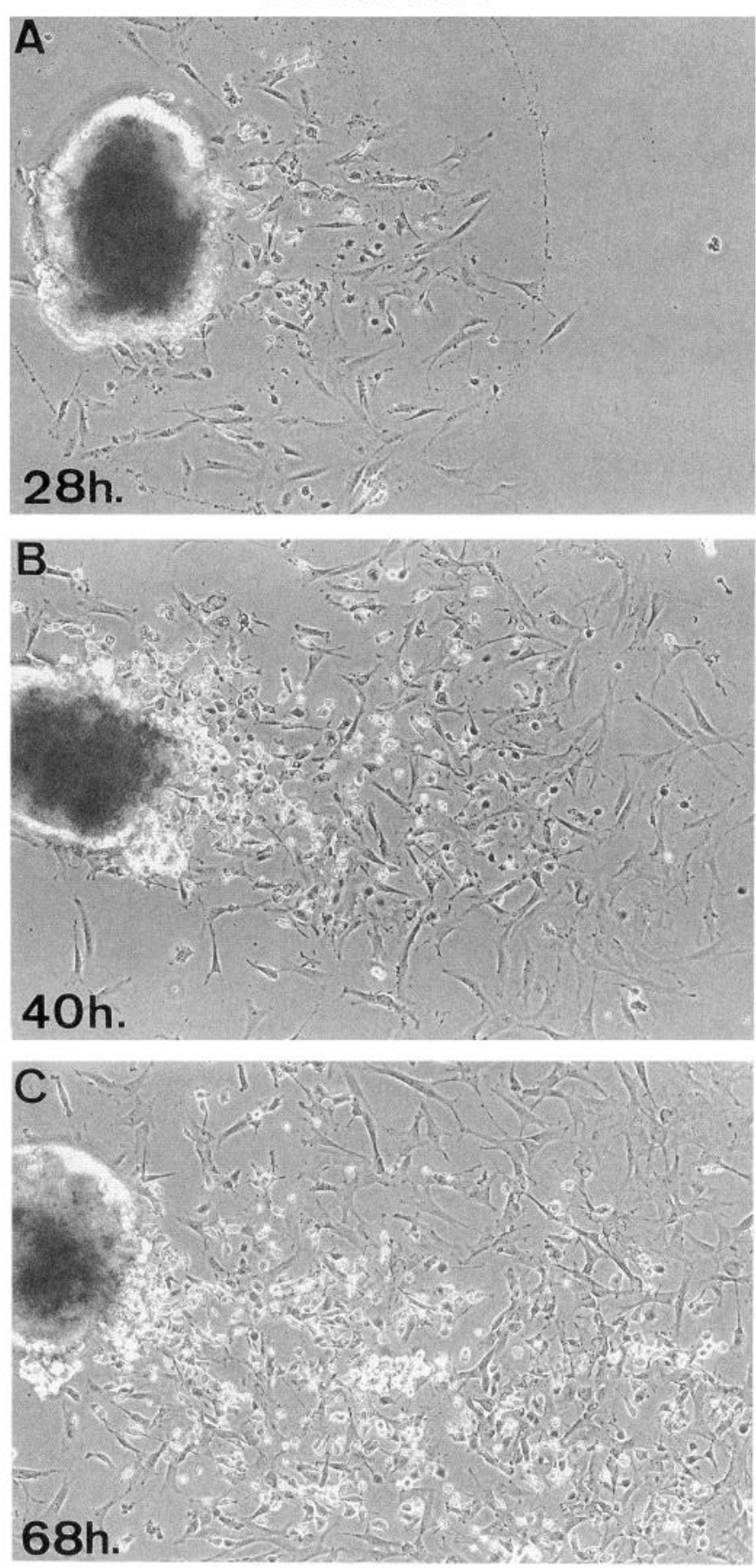

ENDO-N
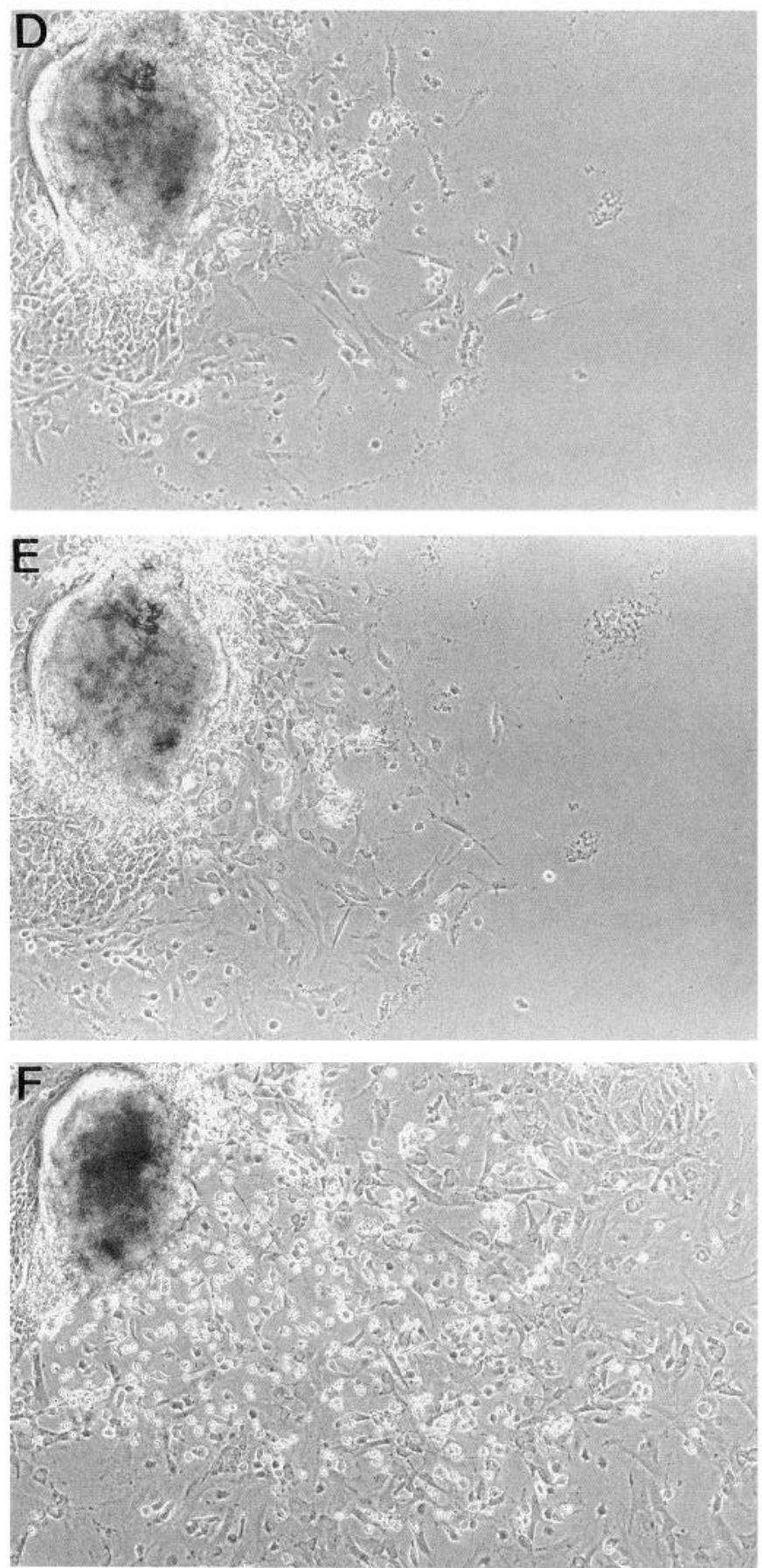

\section{Experimental Protocol}

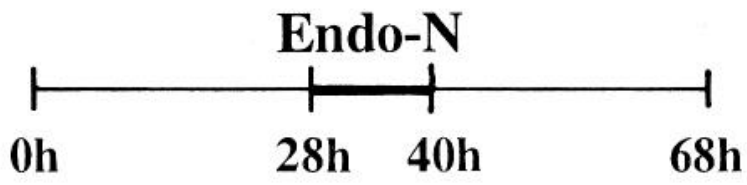

Figure 6. Sequential photography showing the effect of $12 \mathrm{hr}$ transient Endo-N treatment on the cellular outgrowth. Phase-contrast photomicrographs of a representative control and a treated live explant were taken after 28,40 , and $68 \mathrm{hr}$ in culture. The Endo-N treated group was initially cultured in normal medium, subsequently treated with the enzyme for $12 \mathrm{hr}$, and then cultured again in normal medium without the enzyme for an additional $28 \mathrm{hr}$. In the control, there is a continuous expansion of the outgrowth zone throughout the $68 \mathrm{hr}$ culture period $(A-C)$. Inclusion of Endo- $\mathrm{N}$ in the medium produces a complete but reversible blockade of cell migration $(E, F)$. Magnification, $64 \times$. 
positive cells were seen in the outgrowth, among which about $19 \pm 7(n=3)$ were PSA positive. There was no PSA-positive, GFAP-negative cell in the outgrowth region.

In cultures treated with Endo- $\mathrm{N}$, there was a complete absence of PSA-positive cells in the outgrowth (data not shown); this disappearance of PSA-positive cells correlated with an absence of A2B5/GFAP-positive type 2 astrocytes (Fig. 5A,B). The treatment also eliminated PSA staining within the explant while that of total NCAM and GFAP were not affected (Fig. $5 A, B$ ). These effects of Endo-N treatment were reproducible and specific: the enzymatic treatment did not appear to influence the migration of other cells either negative (Fig. $5 A, B$ ) or positive [an average of $6 \pm 1(n=3)$ type 1 astrocytes were observed around the explant] for GFAP. Moreover, when the same experiment was conducted on cultures prepared from PN6, type 1 astrocytes characterized by their morphology and GFAP staining were still coming out of the explant (data not shown); therefore, the action of Endo-N seems to affect only PSA-positive cells, which are, in our model, mainly O-2A progenitor cells.

To exclude the possibility that a selective death of the progenitor due to the enzymatic treatment was responsible for the absence of O-2A lineage cells in the cellular outgrowth, we tested the reversibility of the effect of Endo-N. Cultures were treated for $40 \mathrm{hr}$ with Endo- $\mathrm{N}$, and then washed and maintained in serum-complemented medium without enzyme for an additional $36 \mathrm{hr}$. In these cultures GFAP/A2B5-positive type 2 astrocytes were readily detectable [an average of $10 \pm 1(n=3)$ cells per explant] in the outgrowth region (Fig. $5 C, D$ ). In an other series of experiments, the enzymatic treatment was started on the second day of culture, when various numbers of progenitor type cells were already present in the migratory zone (Fig. 6). The expansion of the cellular outgrowth has been completely arrested during the period of $12 \mathrm{hr}$ Endo-N treatment, as compared to controls (Fig. 6E); however, upon removal of the enzyme, cells started to migrate again, producing a significant increase of the outgrowth zone (Fig. $6 F$ ). Thus, the enzyme did not influence the viability of cells.

\section{Discussion}

In vivo as well as cell culture experiments have shown that O-2A progenitor cells but not oligodendrocytes, or type 2 astrocytes, are highly motile (Lachapelle et al., 1984; Wolf et al., 1986; Small et al., 1987; Balaban and Small, 1989). In the present study we demonstrate that $\alpha$ 2-8 linked PSA expression is necessary for O-2A progenitor migration. The experimental evidence includes the following: (1) PSA immunoreactivity is specifically expressed on the surface of O-2A progenitors; (2) removing the PSA by Endo-N treatment prevents the migration of these cells but not that of PSA-negative cells (fibroblast, type 1 astrocytes); (3) this effect is reversible; that is, cells of the O-2A lineage become detectable in the migrating population upon cessation of Endo- $\mathrm{N}$ treatment. These findings may be relevant to the migration of $\mathrm{O}-2 \mathrm{~A}$ progenitors during in vivo myelin formation.

Cells of the O-2A lincage are most frequently obtaincd from perinatal optic nerves, but they have also been characterized from various other brain structures including the cerebral cortex (Behar et al., 1988; Levine, 1989), brainstem (Dutly and Schwab, 1991), or cerebellum (Levi et al., 1986). In this study we show that explant cultures of the rat NH can also be used to obtain these cells: individual cells are rapidly dispersed from explants of perinatal age and cells of the $\mathrm{O}-2 \Lambda$ lineage predominate in this migrating cell population. Our evidence is based on the following observations. First, the presumed progenitor cells were A2B5, vimentin immunoreactive and exhibited a morphology analogous to what has been described for $\mathrm{O}-2 \mathrm{~A}$ cells isolated from the optic nerve (see Raff, 1989, for review). Second, in the presence of serum, these cells were accompanied by type 2 astrocytes, whereas in serum-free medium type 2 astrocytes were replaced by oligodendrocytes or O4-positive immature forms of oligodendrocytes. Thus, similarly to O-2A precursor from the rat optic nerve, progenitor cells from the perinatal $\mathrm{NH}$ are bipotential. Previous studies have suggested that type 2 astrocytes in cultures of hypothalamic cells could also be derived from large epithelioid-shaped, type 1 astrocytes (Madarasz et al., 1991). This is probably not the case in our culture model, since type 2 astrocytes as well as other $0-2 \mathrm{~A}$ lineage cells were found only in a specific developmental period including E21 and PN3, when type 1 astrocytes were virtually absent in the migratory population. It is equally unlikely that type 2 astrocytes are derived from type 1 astrocytes inside the explant and then spread away from the explants, since type 2 astrocytes are not motile cells (Small et al., 1987). Finally, the fact that the enzymatic removal of PSA resulted in a simultaneous disappearance of the progenitor and type 2 astrocytes in the outgrowth (see Results) further confirms the developmental relationship between the two cell types

We found that virtually all A2B5-positive O-2A progenitor cells as well as $\mathrm{O} 4$-positive immature oligodendrocytes from NH cultures express GFAP immunoreactivity. This is in apparent contradiction with the widely accepted view that $\mathrm{O}-2 \mathrm{~A}$ cells as well as oligodendrocytes are GFAP negative, though a small number of isolated cells from different brain regions have been shown to coexpress GFAP and O4 (Sommer and Schachner, 1981; Levi et al., 1986; Lillien et al., 1988; Trotter and Schachner, 1989; Vaysse and Goldman, 1990; Dutly and Schwab, 1991). Based on these observations, it has been proposed that $\mathrm{O}-2 \mathrm{~A}$ progenitor may transiently express GFAP before going on to become oligodendrocytes (Lillien and Raff, 1990). Our finding that the large majority of precursor cells and O4-positive cells are GFAP positive might reflect their in vivo commitment toward the astrocytic phenotype. Thus, it is possible that pituicytes, or at least some of them, could develop from O-2A progenitors. This possibility is supported by the observation that $\mathrm{O}-2 \mathrm{~A}$ progenitors are present during a specific developmental period (see Table 1) that corresponds to the time when pituicytes differentiate in vivo (Galabov and Schiebler, 1978). Since the NH is highly vascularized and lacks a blood-brain barrier, it is feasible that serum-derived factors necessary for the differentiation of $\mathrm{O}-2 \mathrm{~A}$ cells into type 2 astrocyte are made available through the fenestrated capillaries. However, we cannot exclude the possibility that the explantation procedure may release growth factors such as ciliary neurotrophic factor, which in turn increases GFAP expression in progenitors. Whatever the case, our results raise the possibility that astrocytes developed for $\mathrm{O}-2 \mathrm{~A}$ progenitors may have an important role in neuroendocrine organs such as the NH.

We have demonstrated that enzymatic treatment with Endo-N results in a complete and specific blockage of $\mathrm{O}-2 \mathrm{~A}$ lineage migration from explants. Previous studies have conclusively shown that Endo-N-induced effects can be attributed to the removal of PSA from NCAM (Rutishauser et al., 1985; Zhang et al., 1992). Indeed, we observed after Endo-N treatment a 
virtually complete elimination of PSA immunoreactivity (see Results). The enzyme was shown to degrade rapidly and specifically linear homopolymers of sialic acid with $\alpha 2-8$ linkage, which requires a minimum chain length of seven to nine residues (Vimr et al., 1984). In the nervous system, $\alpha$ 2-8 polysialic acid glycans with chain length in excess of 10 sialosyl residues have so far been described in association predominantly with NCAM, although a recent study suggests that sodium channels may also carry homopolymers of $\alpha$ 2-8 linked PSA (Zuber et al., 1992). The observation that dispersion of non-PSA-expressing cells (type 1 astrocytes or fibroblast) from explants (see Results) was not affected by Endo- $N$ further confirms the specificity of the enzymatic treatment.

Our data represent direct evidence for the contribution of PSA to the motility of migratory cells. The expression of PSA on NCAM is both temporally and spatially regulated during development (for review, see Edelman, 1986; Rutishauser and Landmesser, 1991). A common denominator between cells expressing PSA is that they all display a certain developmental plasticity and potential to change their shape or to migrate (Rougon et al., 1993). Such a permissive role of PSA has already becn postulated on the basis of correlative data. In the developing cerebellum, for instance, it was possible to establish a clear correlation between the expression of PSA-NCAM and granule cell migration (Hekmat et al., 1990): granule cells express PSA-NCAM expression before and during migration, but this immunoreactivity is not detectable when cells reach their final destination in the internal granule layer. In evaluating the physiological relevance of our findings in vitro, it is of particular importance that the elaboration of myelin in cerebellar white matter coincided with the detectability of PSA-NCAM (Hekmat et al., 1990). Correlative studies have also suggested that polysialylation of NCAM in certain cancer cells may reduce homophilic adhesion and increase metastatic potential (see Jin et al., 1991, for review). The present demonstration that PSA is required for the migration of a specific population of cells from an initially coherent tissue, may be relevant to this hypothesis.

The mechanism by which PS $\Lambda$ contributes to $O-2 \Lambda$ cell motility has not been addressed in the present study and, more generally, mechanisms by which PSA regulates cell-cell interactions are not clear. Its negative regulatory role could easily be envisioned as a direct inhibition of NCAM functions. In recent studies, however, removal of PSA had an effect even when NCAM functions were blocked by antibodies, and PSA was shown to modulate interactions in the absence of NCAM-mediated adhesion (Acheson et al., 1991). These observations support the hypothesis that PSA on NCAM may act as a global inhibitor of cell adhesion and affect a broad spectrum of cell interactions mediated by other receptors (Rutishauser et al., 1988; Acheson et al., 1991). Furthermore, the roles played by PSA NCAM in cell migration are likely to be complex; in addition to a merely steric role, it may also serve as a signaltransducing transmembrane molecule (Schuch et al., 1989). For example, transfection of human NCAM cDN $\Lambda$ into mouse L cells or 3T3 fibroblasts resulted in cell surface expression of NCAM isoforms, leading to PSA-dependent increase of axonal outgrowth in neuronal cocultures; evidence was presented that the promotion of neurite outgrowth by PSA-NCAM involves $\mathrm{G}$-protein-dependent activation and increased calcium influx through L-and N-type channels (Doherty et al., 1990, 1991; Williams et al., 1992). Which of the above mechanisms is involved in the motility of $\mathrm{O}-2 \mathrm{~A}$ cells remains to be determined.

\section{References}

Abney ER, Bartlett PP, Raff MM (1981) Astrocytes, ependymal cells, and oligodendrocytes develop on schedule in dissociated cell cultures of embryonic rat brain. Dev Biol 83:301-310.

Acheson A, Sunshine JL, Rutishauser U (1991) NCAM polysialic acid can regulate both cell-cell and cell-substrate interactions. J Cell Biol 114:143-153.

Balaban E, Small R (1989) The use of avian chimaeras to study the origin of myelin-forming cells in the optic nerve. J Cell Biol 109:58a.

Behar I, McMorris FA, Novotny EA, Barker JL, Dubois-Dalcq M (1988) Growth and differentiation properties of $\mathrm{O}-2 \mathrm{~A}$ progenitors purified from rat cerebral hemispheres. J Neurosci Res 21:168-180.

Bensted JP, Dobbing MJ, Morgan RS, Reid RTW, Payling Wright G (1957) Neuroglial development and myelination in the spinal cord of the chick embryo. J Embryol Exp Morphol 5:428-437.

Bignami A, Dahl D (1974) Astrocyte-specific protein and neuroglial differentiation. An immunofluorescence study with antibodies to GFAP. J Comp Neurol 153:27-38.

Bottenstein JE (1984) Culture methods for growth of neuronal cell lines in defined media. In: Methods for serum-free culture of neuronal and lymphoid cells (Barnes DW, Sirbasku DA, Sato GH, eds), pp 313. New York: Liss.

Cameron RS, Rakic P (1991) Glial cell lineage in the cerebral cortex: a review and synthesis. Glia 4:124-137.

Ciesielski-Treska J, Ulrich G, Aunis D (1991) Protein kinase C-induced redistribution of the cytoskeleton and phosphorylation of vimentin in cultured brain macrophages. J Neurosci Res 29:362-378.

Dellmann H-D, Gabrion J, Privat A (1991) Fine structural changes in explants of the neural lobe of the rat hypophysis. J Neuroendocrinol 3:339-347.

Doherty P, Cohen J, Walsh FS (1990) Neurite outgrowth in response to transfected N-CAM changes during development and is modulated by polysialic acid. Neuron 5:209-219.

Doherty P, S Ashton V, Moore SE, Walsh FS (1991) Morphoregulatory activities of NCAM and N-cadherin can be accounted for by $\mathrm{G}$ protein-dependent activation of $\mathrm{L}$-and $\mathrm{N}$-type neuronal $\mathrm{Ca}^{2+}$ channels Cell 67:21-33.

Dubois-Dalcq M (1987) Characterization of a slowly proliferative cell along the oligodendrocyte differentiation pathway. EMBO J 6:25872595.

Dubois-Dalcq M, Behar T, Hudson L, Lazzarini RA (1986) Emergence of three myelin proteins in oligodendrocytes cultured without neurons. J Cell Biol 102:384-392.

Dutly F, Schwab ME (1991) Neurons and astrocytes influence the development of purified O-2A progenitor cells. Glia 4:559-571.

Edelman GM (1986) Cell adhesion molecules in the regulation of animal form and tissue pattern. Annu Rev Cell Biol 2:81-116.

Eisenbarth GS, Walsh FS, Niremberg M (1979) Monoclonal antibody to a plasma membrane antigen of neurons. Proc Natl Acad Sci USA 76:4913-4917.

Eng LF, Vanderheagen JJ, Bignami A, Gerstl B (1971) An acidic protein isolated from fibrous astrocytes. Brain Res 28:351-354.

Finne J, Mäkela PH (1885) Cleavage of polysialosyl units of brain glycoproteins by a bacteriophage endosialidose. J Biol Chem 260 : 1265-1270.

Galabov P, Schiebler TH (1978) The ultrastructure of the developing neural lobe. Cell Tissue Res 189:313-329.

Hallenbeck PC, Vimr ER, Yu F, Bassler B, Troy FA (1987) Purification and properties of a bacteriophage-induced Endo- $\mathrm{N}$-acetylneuraminidase specific for poly $\alpha 2,8$-sialosyl carbohydrate units. J Biol Chem 262:3553-3561.

Hartman BK, Agrawal HC, Kalmbach S, Shearer WT (1979) A comparative study of the immunohistochemical localisation of basic protein to myelin and oligodendrocytes in rat and chicken brain. J Comp Neurol 188:273-290.

Hatton GI (1990) Emerging concepts of structure-function dynamics in adult brain: the hypothalamoneurohypophysial system. Prog Neurobiol 34:437-504.

Hekmat A, Bitter-Suermann D, Schachner M (1990) Immunocytological localization of the highly polysialylated form of the neural cell adhesion molecule during development of the murine cerebellar cortex. J Comp Neurol 291:457-467.

Hoffman S, Edelman GM (1983) Kinetics of homophilic binding by embryonic and adult forms of the neural cell adhesion molecule. Proc Natl Acad Sci USA 80:5762-5766. 
Jacque C, Quinonero J, Collins PV, Villarroya H, Suard I (1992) Comparative migration and development of astroglial and oligodendroglial cell populations from a brain xenograft. J Neurosci 12:3098-3106.

Jin L, I Iemperly JJ, Lloyd RV (1991) Expression of neural cell adhesion molecule in normal and neoplastic human neuroendocrine tissues. Am J Pathol 138:961-969.

Kiss JZ, Wang C, Rougon G (1993) Nerve-dependent expression of high polysialic acid neural cell adhesion molecule in neurohypophysial astrocytes of adult rats. Neuroscience 53:213-221.

Kristensson K, Zeller NK, Dubois-Dalcq ME, Lazzarini RA (1986) Expression of myelin basic protein gene in the developing rat brain as revealed by in situ hybridization. J Histochem Cytochem 34:467473.

Lachapelle F, Gumpel M, Baulac M, Jacque C, Duc P, Baumann F (1984) Transplantation of CNS fragments into the brain of shiverer mutant mice: extensive myelination by implanted oligodendrocytes. I. Immunohistochemical studies. Dev Neurosci 6:325-334.

Levi G, Gallo V, Ciotti MT (1986) Bipotential precursors of putative fibrous astrocytes and oligodendrocytes in rat cerebellar cultures express distinct surface features and "neuron-like" gamma-aminobutyric acid transport. Proc Natl Acad Sci USA 83:1504-1508.

Levine J (1989) Neuronal influences on glial progenitor cell development. Neuron 3:103-113.

LeVine SM, Goldman JE (1988) Ultrastructural characteristics of GD3 ganglioside-positive immature glia in rat forebrain white matter. $\mathbf{J}$ Comp Neurol 277:456-464.

Levison SW, Goldman JE (1993) Both oligodendrocytes and astrocytes develop from progenitors in the subventricular zone of postnatal rat forebrain. Neuron 10:201-212.

Lillien LE, Raff MC (1990) Analysis of the cell-cell interactions that control type-2 astrocyte development. Neuron 4:525-543.

Lillien LE, Sendtner M, Rohrer H, Huges SM, Raff MC (1988) Type-2 astrocyte development in rat brain cultures is initiated by a CNTFlike protein produced by type- 1 astrocytes. Neuron 1:485-49,4

Madarasz E, Theodosis DT, Poulain DA (1991) In vitro formation of type 2 astrocytes derived from postnatal rat hypothalamus or cerebral cortex. Neuroscience 43:211-221.

McMorris FA, Smith TM, DeSalvo S, Furlanetto RW (1986) Insulinlike growth factor I/somatomedin C: a potent inducer of oligodendrocyte development. Proc Natl Acad Sci USA 83:822-826.

Miller RH, David S, Patel R, Abney ER, Raff MC (1985) A quantitative immunohistochemical study of macroglial cell development in the rat optic nerve: in vivo evidence for two distinct astrocyte lineages. Dev Biol 111:35-41.

Noble M, Murray K, Stroobant P, Waterfield MD, Riddle P (1988) Platelet-derived growth factor promotes division and inhibits premature differentiation of the oligodendrocyte/type- 2 astrocyte progenitor cell. Nature 333:560-562.

Raff MC (1989) Glial cell diversification in the rat optic nerve. Science 243:1450-1455

Raff MC, Miller RH, Noble M (1983) A glial progenitor cell that develops in vitro into an astrocyte or an oligodendrocyte depending on culture medium. Nature 303:390-396.

Raff MC, Lillien LE, Richardson WD, Burne JF, Noble MD (1988) Platelet-derived growth factor from astrocytes drives the clock that times oligodendrocyte development in culture. Nature 333:562-565.

Ranscht B, Clapshaw P, Price J, Noble M, Seifert W (1982) Development of oligodendrocytes and Schwann cells studied with a monoclonal antibody against galactocerebroside. Proc Natl Acad Sci USA 79:2709-2713

Rougon G, Marshak D (1986) Structural and immunological characterization of the amino-terminal domain of mammalian neural cell adhesion molecules. J Biol Chem 261:3396-3401.

Rougon G, Dubois C, Buckley N, Magnani JL, Zollinger W (1986) A monoclonal antibody against meningococcus group $\mathrm{B}$ polysaccharides distinguishes embryonic from adult N-CAM. J Cell Biol 103:24292437.

Rougon G, Olive S, Figarella-Branger D (1993) Is PSA-NCAM a marker for plasticity? In: Polysialic acid (Roke J, Rutishauser V, Troy $\mathrm{F}$, eds), pp 323-333. Basel: Birkhäuser.

Rutishauser U, Landmesser L (1991) Polysialic acid on the surface of axons regulates patterns of normal and activity-dependent innervation. Trends Neurosci 14:528-532.

Rutishauser U, Hoffman S, Edclman GM (1982) Binding propcrtics of a cell adhesion molecule from neural tissue. Proc Natl Acad Sci USA 79:685-689.
Rutishauser U, Watanabe M, Silver J, Troy FA, Vimr ER (1985) Specific alteration of NCAM-mediated cell adhesion by an Endoneuraminidase. J Cell Biol 101:1842-1849.

Rutishauser U, Acheson A, Hall AK, Mann D, Sunshine J (1988) The neural cell adhesion molecule (NCAM) as a regulator of cell-cell interactions. Science 240:53-57.

Sadoul R, Hirn M, Deagostini-Bazin H, Rougon G, Goridis C (1983) Adult and embryonic mouse neural cell adhesion molecules have different binding properties. Nature 304:347-349.

Salm AK, Hatton GI, Nilaver G (1982) Immunoreactive glial fibrillary acidic protein in pituicytes of the rat neurohypophysis. Brain Res 236 : $471-476$.

Schuch U, Lohse MJ, Schachner M (1989) Neural cell adhesion molecules influence second messenger systems. Neuron 3:13-20.

Schwab ME, Caroni P (1988) Oligodendrocytes and CNS myelin are nonpermissive substrates for neurite growth and fibroblast spreading in vitro. $\mathrm{J}$ Neurosci 8:2381-2393.

Schwab ME, Schnell L (1989) Region-specific appearance of myelin constituents in the developing rat spinal cord. J Neurocytol 18:161169.

Skoff RP (1990) Gliogenesis in rat optic nerve: astrocytes are generated in a single wave before oligodendrocytes. Dev Biol 139:149-168.

Small RK, Riddle P, Noble M (1987) Evidence for migration of oligodendrocyte-type 2 astrocyte progenitor cells into the developing rat optic nerve. Nature 328:155-157.

Sommer I, Schachner M (1981) Monoclonal antibodies $\left(\mathrm{O}_{1}\right.$ to $\left.\mathrm{O}_{1}\right)$ to oligodendrocyte cell surfaces: an immunocytological study in the central nervous system. Dev Biol 83:311-327.

Suess U, Pliska V (1981) Identification of the pituicytes as astroglial cells by indirect immunofluorescence-staining for the glial fibrillary acidic protein. Brain Res 221:27-33.

Theodosis DT, Poulain DA (1984) Evidence for structural plasticity in the supraoptic nucleus of the rat hypothalamus in relation to gestation and lactation. Neuroscience 11:183-193.

Theodosis DT, Rougon G, Poulain DA (1991) Retention of embryonic features by an adult neuronal system capable of plasticity: polysialylated neural cell adhesion molecule in the hypothalamo-neurohypophysial system. Proc Natl Acad Sci USA 88:5494-5498.

Trotter J, Schachner M (1989) Cell positive for $\mathrm{O}_{4}$ surface antigen isolated by cell sorting are able to differentiate into astrocytes or oligodendrocytes. Dev Brain Res 46:115-122.

Trotter J, Bitter-Suermann D, Schachner M (1989) Differentiationregulated loss of the polysialylated embryonic form and expression of the different polypeptides of the neural cell adhesion molecule by cultured oligodendrocytes and myelin. J Neurosci Res 22:369-383.

Vaysse PJ-J, Goldman JE (1990) A clonal analysis of glial lineages in neonatal forebrain development in vitro. Neuron 5:227-235.

Vimr ER, McCoy RD, Vollger HF, Wilkison NC, Troy FA (1984) Use of prokaryotic-derived probes to identify poly(sialic acid) in neonatal neuronal membranes. Proc Natl Acad Sci USA 81:1971-1975.

Wang C, Rougon G, Kiss JZ (1993) Requirement of polysialic-acid for the migration of the O-2A glial progenitor cell in vitro. Soc Neurosci Abstr 19:1117.

Watanabe M, Frelinger AL, Rutishauser U (1986) Topology of NCAM structural and functional determinants. I. Classification of monoclonal antibody epitope. J Cell Biol 103:1721-1727.

Williams BP, Abney ER, Raff MC (1983) Macroglial cell development in embryonic rat brain: studies using monoclonal antibodies, fluorescence activated cell sorting and cell culture. Dev Biol 100:166171

Williams EJ, Doherty P, Turner G, Reid RA, Hemperly JJ, Walsh FS (1992) Calcium influx into neurons can solely account for cell contact-dependent neurite outgrowth stimulated by transfected L1. J Cell Biol 119:883-892

Wolf MK, Brandenberg MC, Billings-Gagliardi S (1986) Migration and myelination by adult glial cells: reconstructive analysis of tissue culture experiments. J Neurosci 6:3731-3738.

Zhang H, Miller RH, Rutishauser U (1992) Polysialic acid is required for optimal growth of axons on a neuronal substrate. J Neurosci 12: 3107-3114.

Zuber C, Lackie PM, Catteral WA, Roth J (1992) Polysialic acid is associated with sodium channels and the neural cell adhesion molecule N-CAM in the adult rat brain. J Biol Chem 267:9965-9971. 